\title{
New Species Records for the Flora of Burkina Faso
}

\author{
Received: 2018-11-13; accepted: 2018-11-20
}

\author{
Marco Schmidt ${ }^{1,2}$ \\ ${ }^{1}$ Senckenberg Biodiversität und Klima Forschungszentrum (SBiK-F), Senckenberganlage 25, 60325 Frankfurt, Germany \\ mschmidt@senckenberg.de \\ ${ }^{2}$ Palmengarten der Stadt Frankfurt, Siesmayerstraße 61, 60323 Frankfurt, Germany
}

Summary: Since the last comprehensive publication on Burkina Faso's flora, further species have been documented in publications and online resources. These thirteen species are listed here with notes on ecology, use and distribution. The number of vascular plants known for Burkina Faso has therefore reached 2080 species.

Key words: Burkina Faso, Flora, Vascular Plants

\section{NouVEAUX ENREgistrementS D'espèces POUR LA FLORE DU BURKINA FAso}

Résumé: Depuis la dernière publication complète de la flore du Burkina Faso, d'autres espèces ont été publiées dans des publications et des ressources en ligne. Ces treize espèces sont listées ici avec des notes sur l'écologie, l'utilisation et la répartition. Le nombre de plantes vasculaires connues pour le Burkina Faso a ainsi atteint 2080 espèces.

Mots clés: Burkina Faso, Flore, Plantes vasculaires

\section{Neue Artnachweise für die Flora von Burkina Faso}

Zusammenfassung: Seit der letzten umfassenden Veröffentlichung zur Flora von Burkina Faso wurden weitere Arten in Publikationen und Online-Ressourcen veröffentlicht. Diese dreizehn Arten werden hier mit Anmerkungen zu Ökologie, Verwendung und Verbreitung aufgeführt. Die Anzahl der für Burkina Faso bekannten Gefäßpflanzen hat somit 2080 Arten erreicht.

Schlagworte: Burkina Faso, Flora, Gefäßpflanzen

\section{INTRODUCTION}

Burkina Faso's known flora has been comprehensively assessed by GuINKo (1984; 1054 species), followed by LEBRUN et al. (1991; 1203 species) and finally by Thiombiano et al. (2012; 2067 species). However, in the meantime a number of new plant species have been documented for Burkina Faso. Contemporaneously with the vascular plant catalogue, a field guide to Burkina Faso's trees has been published (SACANDÉ et al. 2012), with a few species hitherto undocumented. Other species have been found during fieldwork and documented by herbarium specimens or photo records, some have been previously overlooked in herbarium collections. These new records are presented here to update the knowledge of Burkina Faso's flora.

\section{Methods}

Since the publication of the catalogue of vascular plants (ThiоmBiano et al. 2012), several species have been newly documented for Burkina Faso. Some of these have been listed in the tree guide by SACANDÉ et al. (2012), others found in photo records contributed to African Plants - a photo guide (DRESSLER et al. 2014) or in herbarium specimens contributed to JSTOR Global Plants (https://plants.jstor.org). For consistency with Burkina's vascular plant catalogue, we present these species in the same format. The synonymy and higher taxon affiliation follows the African Plants Database (KLOPPER et al. 2006). 
3 Results

\section{APOCYNACEAE}

Adenium obesum (Forssk.) Roem. \& Schult.

References: $\quad$ SACANDÉ et al. 2012: 71; FWTA 2: 76.

Vern. names: Rose du désert, Baobab chacal (French).

Life Form: Phanerophyte.

Habitat: $\quad$ Savanna, on stony or sandy soils.

Distribution: Tropical Africa, Arabian peninsula.

SACANDÉ et al. (2012) mention this species to occur in Burkina Faso. This species is documented by a photo record of a cultivated plant from Banfora by S. Porembski in DressLER et al. (2014), and a herbarium specimen (Chevalier 530) mentioned by HUBER (1963), who further expressed doubts about the species being native to West Africa.

\section{Ceropegia meyeri-johannis Engl.}

References: $\quad$ LISOWSKI \& MALAISSE 1974.

Life Form: Geophyte (climber).

Habitat: Woodlands.

Distribution: Subsaharan Africa.

This species has been documented by a photo record from the Falaise de Banfora by S. Porembski (in Dressler et al. 2014).

\section{Ceropegia purpurascens K. Schum.}

Life Form: $\quad$ Geophyte (climber).

Distribution: Subsaharan Africa.

This species has been documented by a photo record from tiger bush vegetation in the Sahel Reserve by A. Erpenbach (in DressLer et al. 2014).

\section{Tylophora sylvatica Decne.}

References: Akok̀Gninou et al. 2006: 374; FWTA 2: 96.

Life Form: $\quad$ Geophyte (climber).

Habitat: Thickets.

Distribution: Tropical Africa and Madagascar.

This species has been documented by a photo record from the Comoé-Léraba reserve by A. Thiombiano (in DRESSLER et al. 2014).

\section{ASPARAGACEAE}

\section{Albuca abyssinica Jacq.}

References: FWTA 3: 103.

Life Form: Geophyte.

Habitat: Wet places in hilly savanna, rocks.

Distribution: Subsaharan Africa, Arabian peninsula.

This species has been documented by a photo record from the Cascades de Karfiguela by M. Schmidt (in DressLer et al. 2014) and a herbarium specimen from the same location (SCHMIDT et al. 6464, FR).

\section{BEGONIACEAE}

\section{Begonia rostrata Welw. ex Hook. f.}

References: $\quad$ FWTA 1:219.

Life Form: Therophyte (succulent).

Habitat: Moist rocks.

Distribution: Subsaharan Africa.

This species has been documented by a photo record from the Falaise de Banfora by S. Porembski (in Dressler et al. 2014). A Begonia specimen from Chaine de Gobnangou (O. Bognounou 45, 9.1.1970, HNBU) is probably also B. rostrata.

\section{CYPERACEAE}

\section{Kyllinga beninensis Samain, Reynders \& Goetgh.}

References: AkoÈGninou et al. 2006: 104; SAmain et al. 2006.

Synonyms: $\quad$ Cyperus beninensis (Samain, Reynders \& Goetgh.) Huygh

Life Form: Geophyte

Distribution: Benin, Burkina Faso.

This species has been documented by a photo record from Pama by A. Lessmeister (in DressLer et al. 2014).

\section{MYRTACEAE}

\section{Eucalyptus citriodora Hook. [cult.]}

References: $\quad$ Sacandé et al. 2012: 137.

Life Form: Phanerophyte.

Other Uses: Timber and firewood. 
Distribution: Originally from Australia, widely cultivated.

\section{ORCHIDACEAE}

\section{Eulophia cucullata (Afzel. ex Sw.) Steud.}

References: $\quad$ AkoÈGNINOU et al. 2006: 153; FWTA 3: 249.

Life Form: Geophyte.

Habitat:

Savanna.

Distribution: Subsaharan Africa, Comores, Madagascar.

This species has been documented by a herbarium specimen from the Sourou valley (D.H. Winkoun 181, 10.7.1957, HNBU). Since it has also been found in Pendjari National Park in northern Benin, it is expected to occur also in neighbouring reserves in Burkina Faso's Southeast.

\section{RUBIACEAE}

\section{Pentodon pentandrus (Schumach. \& Thonn.) Vatke}

References: $\quad$ AkoÈGninou et al. 2006: 896.

Life Form: Therophyte.

Habitat: Wetlands.

Distribution: $\quad$ Subsaharan Africa, Madagascar, Arabian peninsula.

This species has been documented by a photo record from F.Cl. de Téré by M. Schmidt (in DressLer et al. 2014).

\section{RUTACEAE}

\section{Citrus $\times$ aurantiifolia (Christm.) Swingle [cult.]}

References: $\quad$ SACANDÉ et al. 2012: 46; AKoÈGNINOU et al. 2006: 911 .

Vern. names: $\quad$ lembur (Mooré); limettier (French).

Life Form: Phanerophyte.

Food use: $\quad$ Juice of fruits used for drinks and food.

Distribution: Cultivated in tropical countries worldwide.

\section{Citrus maxima (Burm.) Merr. [cult.]}

References: $\quad$ SACANDÉ et al. 2012: 46; AKoÈGNINOU et al. 2006: 912 .
Synonyms:

Citrus grandis (L.) Osbeck

Vern. names: pamplemoussier (French).

Life Form: Phanerophyte.

Food use:

Fruits used for drinks and food.

Distribution: Originally from SE Asia, widely cultivated in tropics and subtropics.

\section{THELYPTERIDACEAE}

\section{Ampelopteris prolifera (Retz.) Copel.}

Synonyms: $\quad$ Dryopteris prolifera (Retz.) C.Chr., Thelypteris prolifera (Retz.) P.J.Vorster

Life Form: Geophyte.

Habitat: Riverine forest.

Distribution: Subsaharan Africa, Madagascar, Tropical Asia and Australia.

This species has been documented by a herbarium specimen from Tonkoroni, Dpt. Nouna (O. Bognounou 54, 7.7.1968, HNBU).

\section{Species records not included}

A number of further species records appear to be not sufficiently documented or doubtful; therefore, we have not included them in the list above.

SACANDÉ et al. (2012) mention Pandanus candelabrum P. Beauv. to occur in Burkina Faso. Known Pandanus records from Burkina Faso however belong to P. senegalensis, previously known as P. brevifrugalis (ThiOMBIANo et al. 2012; BeentJe \& Callmander 2014).

OuôBA et al. (2006) mention Habenaria laurentii De Wild. in their list of medicinal plants from Niangoloko forest. We could not find any photo or specimen from within Burkina Faso, but known occurrences are close to the southern border in Côte d'Ivoire and Benin. Therefore this species probably also occurs in Burkina Faso.

\section{Conclusions}

Despite focussed collecting activities on undersampled areas and habitats (SCHMIDT et al. 2010) in the context of the BIOTA project, leading to an important increase of documented species, the flora of Burkina Faso remains incompletely known. We have found 13 species previously unknown from Burkina Faso and expect further additions to the flora to be discovered in the future. Especially the South Western part of Burkina Faso, bordering Mali and Ivory Coast is rich in habitats and species and may still be explored more thoroughly. Likewise, the vast reserves of the South-East offer 
a range of close-to natural Sudanian savanna habitats serving as a refuge for species unable to cope with the dominating agricultural landscapes. But as our results show, even in the relatively species-poor Sahelian region, new discoveries are still possible.

In order to get a more complete coverage of Burkina Faso's flora, better access to digitized collection objects from herbaria in Burkina Faso would be desirable, as the records of HNBU used above demonstrate. Additional collection activities closing gaps in geographical, ecological and seasonal collection patterns are expected to improve the knowledge on Burkina's Flora. Citizen science projects, like the "BIOTA of the WAP complex" (SCHMIDT et al. 2016) may further contribute valuable records.

\section{REFERENCES}

Akoègninou A, van der Burg WJ, van der Maesen LJG, AdJakidjè V, EsSou JP, Sinsin B \& YÉdomonhan H (ed.) (2006): Flore Analytique du Bénin. Cotonou \& Wageningen: Backhuys.

Beentje HJ \& Callmander MW (2014): Pandanaceae. In: LeBrun JP \& Stork AL (ed.): Tropical African Flowering Plants - Ecology and Distribution, pp. 316-323. Conservatoire et Jardin botaniques de la Ville de Genève.

Dressler S, Schmidt M \& Zizka G. (2014): Introducing African Plants - a Photo Guide - an interactive identification tool for continental Africa. Taxon 63:1159-1161.

GuInko S (1984): Végétation de la Haute Volta. - Dissertation, Université de Bordeaux III.
Klopper RR, Smith GF, Gautier L, Chatelain C \& SpICHIGER R (2006): The African Plant Checklist and Database Project. South African J Bot 72: 342.

Lebrun J-P, Toutain B, Gaston A \& Boudet G (1991): Catalogue des plantes vasculaires du Burkina Faso. Maisons-Alfort: Institut d'elevage et de medecine veterinaire des pays tropicaux.

Lisowski S \& Malaisse F (1974): Le genre Ceropegia L. (Asclepiadaceae) au Shaba (Zaire). Bull du Jard Bot Natl Belgique 44: 401-418.

Ouoba P, LykKe AM, Boussim I \& Guinko S (2006): La flore medicinale de la Forêt Classee de Niangoloko, Burkina Faso. Etudes flore vég Burkina Faso 10: 5-16.

Sacandé M, Sanou L \& Beentje H (2012): Guide d'identification des arbres du Burkina Faso. - Kew: Royal Botanic Gardens.

Samain M-S, Reynders M \& Goetghebeur P (2009): Kyllinga beninensis (Cyperaceae), a new species from Bénin. Novon 16: 516-519.

Schmidt M, Assédé E, Oebel H, FAhr J \& Sinsin B (2016): Biota of the WAP complex - starting a citizen science project for West Africa' $s$ largest complex of protected areas. Flora Veg Sudano-Sambesica 19: 3-6.

Schmidt M, Thiombiano A, OuÉdraogo A, Hahn-HadjaLi K, Dressler S \& ZizKa G (2010): Assessment of the flora of Burkina Faso. In: Van der Burgt XM, van der Maesen LJG \& Onana JM, editors. Systematics and Conservation of African Plants, pp. 571-576. Kew: Royal Botanic Gardens.

Thiombiano A, Schmidt M, Dressler S, Ouédraogo A, HAHN K \& ZizKa G (2012): Catalogue des plantes vasculaires du Burkina Faso. Boissiera 65. - Conservatoire et Jardin botaniques de la ville de Genève, 391 p. 